\title{
Influence of Spacing and Drip Irrigation on Yield Attributes, Productivity and Economics of Pigeonpea (Cajanus cajan L.)
}

\author{
K.T. Jadhav, A.S. Chavan*, S.K. Raskar and R.U. Lahase \\ ARS, Badnapur, Vasantrao naik Marathwada Krishi Vidyapeeth, Parbhani (MS), India \\ *Corresponding author
}

A B S T R A C T

\begin{tabular}{|l|}
\hline Ke y w o r d s \\
$\begin{array}{l}\text { Spacing, Drip } \\
\text { irrigation, Yield, } \\
\text { Pigeonpea }\end{array}$ \\
\hline Article Info \\
\hline $\begin{array}{l}\text { Accepted: } \\
\text { 28 January } 2018 \\
\text { Available Online: } \\
\text { 10 February } 2018\end{array}$ \\
\hline
\end{tabular}

\section{Introduction}

Pigeonpea (Cajanus cajana L. Millsp.) commonly known as red gram, tur or arhar is the fifth prominent legume crop in the world and important crop amongst pulses which ranks second after chickpea in India in terms of area and production. It is originated in South Africa in the areas of Angola and Nile river. This is a short day, often cross pollinated crop belonging to family Leguminoceae. It provides protein rich food, firewood and income for resource poor small farmers. In India, the area under pigeonpea in 2011-12 was 3.86 million hectares with production of 2.90 million tonnes and average productivity of $751 \mathrm{~kg} \mathrm{ha}^{-1}$. Pigeonpea is grown as a sole crop, it is relatively inefficient because of its slow initial growth rate and low harvest index therefore it is grown as 
intercrop, which helps in efficient utilization of available resources for enhancing the productivity and profit. In general surface irrigation methods viz., furrow irrigation and controlled flooding i.e. ridges and furrow are the most common methods of water delivery to pigeon pea. In these methods, appreciable quantity of irrigation water is lost due to conveyance, evaporation and percolation besides low application and distribution irrigation efficiencies. The use of modern irrigation system, like drip provides better crop growth and greater yields, due to efficient use of water and nutrients. Drip irrigation is slow and precise application of water and water is applied in the form of drops directly at the root zone at shorter intervals and thereby it saves water due to reduction in conveyance, percolation, evaporation losses besides improving field application and distribution irrigation efficiencies and ultimately resulting in higher water use efficiency. It was found to be an efficient agronomic management tool that allows precise control of water over the root zone environment of the crop (Bresler, 1977) and often results in consistently high yields (Firake et al., 2000). But till date no systematic work was attempted on drip irrigated red gram.

Due to the growing demand of red gram (dal) and the need to increase irrigation efficiency, drip irrigation is being investigated as a possible alternative in terms of growth and yield response to water, water use and crop coefficients at different crop growth periods, economic viability etc. when grown under water constrained situations during rabi season. For field application, farmers need information on when to irrigate (optimum time) and how much to irrigate (depth of water) at various crop developmental stages and likely response of red gram pod yield to drip irrigation scheduling to maximize water productivity and returns. The high initial investment needed for installing the drip irrigation system remains the main deterrent to its wide spread adoption. The extent to which this discouragement effect is real and the extent to which this effect can be counter balanced by the government subsidy are important policy issues requiring greater attention. Past studies for various drip irrigated crops relied heavily on the experience of one or a few farmers adopting drip irrigation (Sivanappan, 1994). Therefore, there is need to evaluate empirically the economic viability of drip irrigation impact on profitability of red gram.

Efficient application of supplemental irrigation water is extremely crucial. In the past this aspect has been neglected. Currently major water losses $(>40 \%)$ and poor uniformity in water distribution are occurring due to inappropriate surface irrigation methods (Pathak et al., 2009). The modern pressurized irrigation system, namely drip, sprinkler and micro-sprinkler can reduce water losses in application of irrigation coveance, percolation, evaporation etc. moreover can achieve uniform distribution irrespective of type of soil and topography of soil. In view this present investigation entitled as "Studies on response of pigeon pea (Cajanus cajan L. Millsp.) to drip Irrigation.

\section{Materials and Methods}

A field experiment was conducted during the period of 2016-17 at Agriculture Research Station, Badnapur situated at $19^{0} 52^{\prime} 00^{\prime \prime}$ North latitude and $75^{\circ} 44^{\prime} 00^{\prime}$ ' East longitudes at $498 \mathrm{~m}$ altitude above mean sea level on clayey in texture, moderate in available nitrogen $\left(160 \mathrm{~kg} \mathrm{ha}^{-1}\right)$, low in available phosphorus (10 $\left.\mathrm{kg} \mathrm{ha}^{-1}\right)$, high in available potassium $\left(621 \mathrm{~kg} \mathrm{ha}^{-1}\right)$. The soil was moderately alkaline in reaction $(8.13 \mathrm{pH})$. In general, weather conditions were favorable for plant growth and no severe pest and 
diseases noticed during experimentation. The study involved twelve treatment combinations consisting of two factors viz., spacing (three levels: $S_{1}-120 \mathrm{~cm} \times 30 \mathrm{~cm}$ spacing, $S_{2}-120 \mathrm{~cm}$ x $45 \mathrm{~cm}$ spacing, $\mathrm{S}_{3}-120 \mathrm{~cm} \times 60 \mathrm{~cm}$ ) and irrigation levels (irrigation at 50\% Epan through drip $\left(\mathrm{I}_{1}\right)$, irrigation at $75 \%$ Epan through drip $\left(\mathrm{I}_{2}\right)$, irrigation at, $100 \%$ Epan through drip $\left(\mathrm{I}_{3}\right)$, supplemental irrigation at $50 \%$ flowering through furrows $\left(\mathrm{I}_{4}\right)$ were evaluated in factorial randomized block design with three replications. The Each experimental unit was repeated three times $9.60 \times 3.60 \mathrm{~m}^{2}$ size in gross plot and in net plot $7.20 \mathrm{~m} \times 2.40 \mathrm{~m}$ for $90 \times 30$ and $30 \times 60$ $\mathrm{cm}, 7.20 \mathrm{~m} \times 2.70 \mathrm{~m}$ for $90 \times 45 \mathrm{~cm}$. Sowing was completed on $2^{\text {nd }}$ July 2016. The fertilizer dose of 25:50:00 NPK kg ha ${ }^{-1}$ was applied after sowing. The shallow furrows were opened manually in each plot as per treatments and entire quantity of phosphorous (50 kg $\mathrm{P}_{2} \mathrm{O}_{2} / \mathrm{ha}$ ) in the form of single super phosphate and $100 \%$ dose of nitrogen $(25 \mathrm{~kg}$ $\mathrm{N} / \mathrm{ha}$ ) in the form of urea were manually applied uniformly before sowing of pigeonpea crop in both the years. The package of recommended practices was adopted to maintain the crop.

\section{Results and Discussion}

\section{Effects on growth attributes}

\section{Spacing}

Growth attributes viz., plant height, number of functional leaves, mean number of branches, mean total dry matter plant ${ }^{-1}$ were significantly influenced due to spacing treatment at all growth stages except at 30 DAS. Results indicated that $120 \times 60 \mathrm{~cm}$ spacing recorded maximum plant height, number of functional leaves, mean number of branches and total dry matter plant ${ }^{-1}$ at all growth stages followed by $120 \times 45 \mathrm{~cm}$ and 120 x $30 \mathrm{~cm}$ spacing, respectively. Gradual decrease with narrow spacing might be attributed to better moisture, nutrients, sunlight and space under wider spacing compared to narrow spacing, similar results were reported by singh et al.(1994) and Shaikh et al., (1997).

Number of functional leaves and number of branches plant ${ }^{-1}$ under wider spacing might have boosted better total dry matter plant $^{-1}$ under wider spacing because of increased source capacity. Dry matter plant ${ }^{-1}$ is important to have efficient translocation of nutrients and assimilates from source to sink. Moreover, number of branches plant ${ }^{-1}$ are very important in case of crop like pigeon pea in which sink i.e. pods are positively correlated with number of branches which ultimately improves economical yield of crop.

\section{Irrigation levels}

Amongst irrigation levels, irrigation at $75 \%$ Epan through drip showed maximum plant height, number of functional leaves, mean number of branches, mean total dry matter plant $^{-1}$ followed by irrigation at $100 \%$ Epan through drip, irrigation at $50 \%$ Epan through drip and irrigation at $50 \%$ flowering through furrows at harvest, However, growth attributes were comparable under irrigation at $50 \%$ Epan through drip and irrigation at $50 \%$ flowering through furrows at all stages which indicated significance of moisture availability at flowering stage in case of pigeon pea (Basu et al., 2009). Moreover, results revealed that highest irrigation level was not able to improve all growth attributes at all stages which might be due to lower efficiency of root nodules under higher irrigation levels, however, irrigation at $75 \%$ Epan through drip proved better over both its lower and higher irrigation level which indicated that optimum moisture and air are very important to have better growth attributes. Bhowmik et al (1983) and Kalpana and Salvi (2008) asserted 
significance of optimum soil moisture for pigeon pea.

\section{Effect on yield attributes and yield}

\section{Spacing}

Various yield attributes viz., number of pods plant $^{-1}$, weight of pods plant $^{-1}$, seed index were significantly influenced due to three spacings under study, except number of seeds per pod which was not influenced due to spacing effect. Wider spacing, $120 \times 60 \mathrm{~cm}$ recorded significantly maximum number of pods plant ${ }^{-1}$, seed yield plant ${ }^{-1}$ and seed index than $120 \times 45 \mathrm{~cm}$ and $120 \times 30 \mathrm{~cm}$ spacing, respectively. However, $120 \times 60 \mathrm{~cm}$ was comparable with $120 \times 45 \mathrm{~cm}$ in case of weight of pods plant $^{-1}$ and seed index. Improved yield attributes under wider spacing and gradual decrease in yield attribute with decreased spacing was also reported by Saritha et al., (2012) in pigeon pea. This might be attributed to improved growth attributes viz., number of functional leaves, mean number of branches, mean total dry matter plant ${ }^{-1}$ which might have helped in better translocation of nutrients towards yield attributes under wider spacing. Also increased population in narrow spacing might have higher competition for moisture, nutrients, space and sunlight which ultimately produced poor source as compared to wider spacing which ultimately negatively affected sink i.e. yield attributes. Mula et al., (2011) also asserted compensatory behavior of plant densities in case of pigeon pea (Table 1).

\section{Irrigation levels}

Amongst irrigation levels, irrigation at $75 \%$ Epan through drip produced significantly maximum number of pods plant ${ }^{-1}$, weight of pods plant ${ }^{-1}$, seed yield plant ${ }^{-1}$ and seed index than rest of irrigation levels, however, it was comparable to irrigation at $100 \%$ Epan through drip in respect to number of pods plant $^{-1}$ and seed yield plant ${ }^{-1}$. Number of seeds per pod was not significantly influenced due to irrigation levels. Superior performance of irrigation at $75 \%$ Epan through drip over irrigation at $50 \%$ Epan through drip as well as irrigation at $100 \%$ Epan through drip and irrigation at $50 \%$ flowering through furrows might be attributed to optimum availability of moisture as well as aeration under irrigation at 75\% Epan through drip compared to irrigation at $50 \%$ Epan, irrigation at $100 \%$ Epan through drip and irrigation at $50 \%$ flowering through furrows. This indicated significance of aeration and moisture in pigeon pea for better efficiency of nodules and root activity and resulted in better growth attributes and ultimately improved yield attributes. Similar results were reported by Bhowmik et al (1983) and Kalpana and Salvi (2008).

\section{Effect on net monetary returns, gross monetary returns, benefit: cost ratio}

\section{Spacing}

$120 \times 45 \mathrm{~cm}$ spacing recorded significantly maximum net monetary returns, gross monetary returns, benefit: cost ratio than wider spacing $120 \times 60 \quad \mathrm{~cm}$. It was comparable with $120 \times 30 \mathrm{~cm}$ in case of net monetary returns, gross monetary returns and benefit: cost ratio. Improved economics under $120 \times 45 \mathrm{~cm}$ spacing might be due to increased seed yield under both narrow spacings of $120 \times 30 \mathrm{~cm}$ spacing as well as wider spacing 120 x $60 \mathrm{~cm}$ (Table 2).

\section{Irrigation levels}

Amongst irrigation levels, irrigation at $75 \%$ Epan through drip noted maximum net monetary returns, gross monetary returns, benefit: cost ratio than rest of the irrigation levels. Higher seed yields under irrigation at 75\% Epan through drip compensated the cost incurred on installation of drip. Similar results were reported by Pramod et al., (2010). 
Table.1 Growth and yield attributes of pigeonpea at harvest as influenced by various treatments of spacing and drip irrigation

\begin{tabular}{|c|c|c|c|c|c|c|c|}
\hline Treatments & $\begin{array}{l}\text { Plant } \\
\text { height } \\
(\mathrm{cm})\end{array}$ & $\begin{array}{c}\text { Number of } \\
\text { branches }^{-1} \\
\text { plant }^{-1}\end{array}$ & $\begin{array}{l}\text { Dry matter } \\
\text { production } \\
\left(\text { g plant }^{-1}\right)\end{array}$ & $\begin{array}{l}\text { Number of } \\
\text { pods plant }^{-1}\end{array}$ & $\begin{array}{l}\text { Weight of } \\
\text { pod plant }^{-1} \\
\text { (g) }\end{array}$ & $\begin{array}{l}\text { Seed yield } \\
\text { plant }^{-1}(\mathrm{~g})\end{array}$ & $\begin{array}{l}\text { Number of } \\
\text { seed pod }\end{array}$ \\
\hline \multicolumn{8}{|l|}{ Spacings (03) } \\
\hline $120 \times 30 \mathrm{~cm}$ & 173.51 & 15.98 & 105.66 & 217 & 117 & 76 & 3.36 \\
\hline $120 \times 45 \mathrm{~cm}$ & 183.05 & 19.66 & 111.64 & 345 & 192 & 125 & 3.38 \\
\hline $120 \times 60 \mathrm{~cm}$ & 184.91 & 21 & 115.75 & 365 & 206 & 137 & 3.44 \\
\hline $\mathbf{S E} \pm$ & 2.60 & 0.97 & 2.01 & 6.77 & 4.71 & 2.67 & 0.030 \\
\hline CD at $5 \%$ & 7.64 & 2.87 & 5.90 & 19.86 & 13.83 & 7.85 & NS \\
\hline \multicolumn{8}{|l|}{ Irrigations levels (04) } \\
\hline Irrigation at50\% Epan through drip & 178.88 & 17.17 & 109.06 & 303 & 141 & 110 & 3.38 \\
\hline Irrigation at75\% Epan through drip & 188.42 & 22.73 & 117.25 & 330 & 238 & 119 & 3.42 \\
\hline Irrigation at $100 \%$ Epan through drip & 180.48 & 19.84 & 111.66 & 310 & 186 & 116 & 3.40 \\
\hline $\begin{array}{l}\text { Irrigation at } 50 \% \text { flowering through } \\
\text { furrows }\end{array}$ & 174.17 & 15.77 & 106.08 & 294 & 122 & 106 & 3.35 \\
\hline $\mathrm{SE} \pm$ & 3.00 & 1.13 & 2.32 & 7.81 & 5.44 & 3.09 & 0.034 \\
\hline CD at $5 \%$ & 8.82 & 3.31 & 6.82 & 22.93 & 15.56 & 9.07 & NS \\
\hline \multicolumn{8}{|l|}{ Interaction } \\
\hline $\mathrm{SE} \pm$ & 5.21 & 1.95 & 4.02 & 13.54 & 9.43 & 5.35 & 0.059 \\
\hline CD at $5 \%$ & NS & NS & NS & NS & NS & NS & NS \\
\hline General Mean & 180.49 & 18.18 & 111.01 & 309 & 172 & 113 & 3.39 \\
\hline
\end{tabular}


Table.2 Yield and economics of pigeonpea at harvest as influenced by various treatments of spacing and irrigation levels

\begin{tabular}{|c|c|c|c|c|c|c|}
\hline \multirow[t]{2}{*}{ Treatments } & \multicolumn{2}{|c|}{ Yield (kg/ha) } & \multirow{2}{*}{$\begin{array}{c}\text { Cost of } \\
\text { production } \\
(\mathrm{Rs} / \mathrm{ha})\end{array}$} & \multirow{2}{*}{$\begin{array}{c}\text { Gross } \\
\text { realization } \\
\text { (Rs/ha) }\end{array}$} & \multirow{2}{*}{$\begin{array}{c}\text { Net } \\
\text { realization } \\
(\mathrm{Rs} / \mathrm{ha})\end{array}$} & \multirow[t]{2}{*}{ B:C ratio } \\
\hline & Grain & Stalk & & & & \\
\hline \multicolumn{7}{|l|}{ Spacings (03) } \\
\hline $120 \times 30 \mathrm{~cm}$ & 2199 & 3673 & 34986 & 105034 & 70048 & 2.99 \\
\hline $120 \times 45 \mathrm{~cm}$ & 2391 & 4077 & 34983 & 119549 & 84566 & 3.41 \\
\hline $120 \times 60 \mathrm{~cm}$ & 1998 & 3549 & 36646 & 99901 & 63255 & 2.72 \\
\hline $\mathrm{SE} \pm$ & 66.06 & 138.53 & - & 3303.19 & 3303.19 & 0.100 \\
\hline CD at $5 \%$ & 193.77 & 406.33 & - & 9688.52 & 9688.52 & 0.295 \\
\hline \multicolumn{7}{|l|}{ Irrigations levels (04) } \\
\hline Irrigation at50\% Epan through drip & 2011 & 3562 & 36688 & 100531 & 63843 & 2.74 \\
\hline Irrigation at75\% Epan through drip & 2674 & 4527 & 36688 & 133683 & 96995 & 3.64 \\
\hline Irrigation at $100 \%$ Epan through drip & 2239 & 3845 & 36688 & 111969 & 75281 & 3.05 \\
\hline Irrigation at $50 \%$ flowering through furrows & 1929 & 3127 & 29755 & 86461 & 56706 & 2.90 \\
\hline $\mathbf{S E} \pm$ & 76.28 & 159.96 & - & 3814.19 & 3814.19 & 0.116 \\
\hline CD at $5 \%$ & 223.74 & 469.33 & - & 11187.35 & 11187.35 & 0.340 \\
\hline \multicolumn{7}{|l|}{ Interaction } \\
\hline $\mathrm{SE} \pm$ & 132.12 & 277.07 & - & 6606.38 & 6606.38 & 0.201 \\
\hline CD at $5 \%$ & NS & NS & - & NS & NS & NS \\
\hline General Mean & 2163 & 3765 & 35205 & 108161 & 72956 & 3.06 \\
\hline
\end{tabular}


Table.3 Soil moisture studies and water use efficiency of pigeonpea as influenced by various treatments of spacing and irrigation levels

\begin{tabular}{|c|c|c|c|c|}
\hline Treatments & $\begin{array}{l}\text { Cost of } \\
\text { production } \\
\text { (Rs/ha) }\end{array}$ & $\begin{array}{l}\text { Evaporation (mm) } \\
\text { Duration ( } 2^{\text {nd }} \text { July- } \\
30 \text { Dec, 2017) }\end{array}$ & $\begin{array}{c}\text { water } \\
\text { applied }(\mathrm{mm})\end{array}$ & WUE $\left(\mathrm{kg} \mathrm{ha}^{-1} \mathrm{~mm}^{-1}\right)$ \\
\hline \multicolumn{5}{|l|}{ Spacings (03) } \\
\hline $120 \times 30 \mathrm{~cm}$ & 23.83 & 305.5 & 2199 & 7.19 \\
\hline $120 \times 45 \mathrm{~cm}$ & 27.33 & 305.5 & 2391 & 7.82 \\
\hline $120 \times 60 \mathrm{~cm}$ & 29.83 & 305.5 & 1998 & 6.54 \\
\hline $\mathrm{SE} \pm$ & 1.51 & - & - & - \\
\hline CD at $5 \%$ & 4.45 & - & - & - \\
\hline \multicolumn{5}{|l|}{ Irrigations levels (04) } \\
\hline Irrigation at50\% Epan through drip & 24.66 & 259 & 2011 & 7.76 \\
\hline Irrigation at75\% Epan through drip & 30.55 & 383 & 2674 & 6.98 \\
\hline Irrigation at $100 \%$ Epan through drip & 35.44 & 520 & 2239 & 4.30 \\
\hline Irrigation at $50 \%$ flowering through furrows & 17.33 & 60 & 1929 & 32.15 \\
\hline SE \pm & 1.75 & - & - & - \\
\hline CD at $5 \%$ & 5.14 & - & - & - \\
\hline \multicolumn{5}{|l|}{ Interaction } \\
\hline $\mathrm{SE} \pm$ & 3.03 & - & - & - \\
\hline CD at $5 \%$ & NS & - & - & - \\
\hline General Mean & 27.00 & 305.5 & 2171.25 & 10.39 \\
\hline
\end{tabular}




\section{Effect on soil moisture studies}

Significantly more soil moisture at all stages in wader spacing $120 \times 60 \mathrm{~cm}$ over both closer spacing indicated decrease in soil moisture with increase in population which might be attributed to increased demand for transpiration under higher population.

In case of irrigation levels, $100 \%$ Epan through drip showed maximum soil moisture compared to lower levels and irrigation at 50 $\%$ flowering through furrow. This might be due to more application of water under $100 \%$ irrigation through drip. Moreover, under $50 \%$ flowering through furrow there was gradual decrease in soil moisture from November till harvest due to no receipt of rainfall after October and this resulted in lower moisture in $50 \%$ flowering through furrow after October 2016 (Table 3).

\section{Effect on water use efficiency}

Higher Irrigation water use efficiency under $120 \times 45 \mathrm{~cm}$ might be attributed to increased seed yield under spacing of $120 \times 45 \mathrm{~cm}$ compared to $120 \times 30 \mathrm{~cm}$ and $120 \times 60 \mathrm{~cm}$ spacing as applied water was same (305.5 $\mathrm{mm}$ ) for all spacings under study.

In case of irrigation levels higher Irrigation water use efficiency was recorded with irrigation at $50 \%$ flowering through furrows which might be due to very less amount of water applied under irrigation at $50 \%$ flowering through furrows $(60 \mathrm{~mm})$ compared to irrigation at $50 \%$ Epan through drip (259 $\mathrm{mm}$ ), irrigation at $75 \%$ Epan through drip $(383 \mathrm{~mm})$ and irrigation at $100 \%$ Epan through drip $(520 \mathrm{~mm})$, respectively. Although irrigation at $75 \%$ Epan through drip recorded more seed yield it could not gave more Irrigation water use efficiency due to more water applied and comparatively less increase in seed yield compared to irrigation at $50 \%$ Epan through drip and irrigation at 50 $\%$ flowering through furrows, respectively. Thus higher seed yield was masked by higher amount of water applied under irrigation at 75 $\%$ Epan through drip and irrigation at $100 \%$ Epan through drip, respectively for improving water use efficiency in case of pigeon pea.

\section{References}

Basu, T.K. and S.R. Bandyopadhyay. 2009. Productivity of rabi pigeon pea (Cajanus cajan 1. Milsp.) As influenced by scheduling of irrigation. J. of crop and weed. 5(2): 90-91.

Bhowmik, N. N., N. Ghosh and P. B., Chaudhary. 1983. Effect of irrigation and phosphorus on growth and yield of pigeon pea [Cajanus cajan (L.) Millsp]. Indian agric. 27 (4): 343-347.

Bresler, E.1977. Trickle - drip irrigation: Principles and applications to soil water management. Advances in Agronomy. 29: 343-393.

Firake, N.N. and S. H., Shinde. 2000. Irrigation depth and interval in drip irrigation for summer groundnut in Entisols. J. of Maharashtra agric. Univ. 25(2): 201-203.

Kalpana R. and R.V., Salvi. 2008. Effect of irrigation layouts on growth and yield of legumes - a review agric. Rev. 29 (2): $139-144$.

Mula, M.G.; K. B., Saxena; R.V., Kumar and A., Rathore. 2011. Influence of spacing and irrigation on the seed yield of a CMS line 'ICPA 2043' of hybrid pigeon pea. J. of food legumes. 24 (3): 202-206.

Pramod G.; B.T., Pujari; M.K., Basavaraja ; G., Vijaymahantesh and Venkate. 2010. Yield, yield parameters and economics of pigeon pea [Cajanus cajan (L.) Millsp] as influenced by genotypes, planting geometry and protective irrigation, Int. J. of agric. Sci., 6 (2) : 422-425. 
Saritha, K. S.; B. T., Pujari; R., Basavarajappa; M. K., Naik; Rameshbabu; B.K., Desai. 2012. Effect of irrigation, nutrient and planting geometry on yield, yield attributes and economics of pigeon pea. J. agric. Sci.25 (1): 131-133.

Shaik Mohammed. 1997. Relative performance of pigeon pea genotypes and their response to row spacing.
Indian J. Pulses res. 10 (1):14-18.

Singh, R.; I.P.S., Ahlawat and R.K., Sharma. 1994. Effect of plant type, row spacing and population density on growth and yield of pigeon pea grown during summer season. Indian $J$. of agron. 39(4): 573-577.

Sivanappan, R.K. 1994.Prospects of micro irrigation in India. Irrigation and drainage systems. 8: 49-58.

\section{How to cite this article:}

Jadhav, K.T., A.S. Chavan, S.K. Raskar and Lahase, R.U. 2018. Influence of Spacing and Drip Irrigation on Yield Attributes, Productivity and Economics of Pigeonpea (Cajanus cajan L.). Int.J.Curr.Microbiol.App.Sci. 7(02): 3498-3506. doi: https://doi.org/10.20546/ijcmas.2018.702.416 